\title{
Globalization and Transnationalization
}

\author{
Anja Weiß
}

\begin{abstract}
Interest in globalization has gained considerable momentum since the $1980 \mathrm{~s}$ and has prompted fundamental debates in the field of sociology. Nonetheless, sociology has remained nationally framed. Today, the notion that transborder phenomena and perspectives are valid is widely accepted. German-speaking authors have undertaken collective efforts towards more precise theories of globalization and transnationalism: Migration scholars, for instance, have proposed middle-range theories of transnational social space built on empirical research. The Luhmannian school of systems theory has translated a comprehensive theoretical program into research on the diffusion of global standards. Internationally prevalent theoretical approaches, such as postcolonial studies, have inspired research on a broad variety of topics ranging from the global division of labor to the cultural aspects of globalization. And finally, as far as methodology is concerned, country comparisons and qualitative case studies are the most common but are being complemented by innovative approaches.
\end{abstract}

Keywords: Transnationalization, globalization, theory of society, transnational social space, systems theory, field theory

\section{Introduction}

Sociology as a discipline was born during a time of nationalism and nation-state formation. Classic sociological theories in the Global North have thus presupposed that modern states shape societies as nations, which in turn lends legitimacy to collective decision-making within a national framework. In this vein, an idealized version of the modern welfare state informs much sociological research, a tendency that has been criticized as both Eurocentric (Quijano, 2000) and methodologically nationalist (Pries, 2008a).

Some theories, such as Wallerstein's world-systems analysis and postcolonial studies, have always seen the social world as global and relational. They remained on the margins of the discipline until the 1980s, a time when globalization became a buzzword in public discourse and when topics such as migration, cross-border production chains, and global ecological risk drew more general interest. The initial response was for public intellectuals such as Anthony Giddens, David Held, Saskia Sassen, Richard Sennett, Zygmunt Bauman, Martin Albrow, John Urry, and Manuel Castells to propose new takes on theories of society/-ies that centered on a loss of (spatial) structuration and variations or phases in modernization processes and that stressed the importance of networks, fluidity, and sociological imagination (Krossa, 2018). 
In Germany, Ulrich Beck moved from a theory of risk embedded in the national welfare state to a theory of world risk society (Beck, 1999). As a staunch opponent of "methodological nationalism," Beck introduced key proponents of the globalization literature to German audiences (Beck and Poferl, 2010; Beck et al., 2003). He argued that the globalization of risk is a side-effect of modernization that would reflect back on institutions such as the nation state (Beck et al., 2013; cf. Lessenich, 2016). Beck believed this to have consequences for sociology and called for a distinctly sociological cosmopolitan method (Beck, 2014).

Despite these intense and fundamental debates, most sociological work (and administrative data sources) remained nationally framed and most professional sociologists did not feel compelled to translate the public debate on globalization into sociological theory and research. Even in comparative sociology, national path dependencies have mostly been constructed as isolated cases. Although more complex comparative strategies do exist, such as embedded comparison (Tilly, 1984), they remain exceptions (Eigmüller, EUROPE, this volume).

From today's vantage point, we can see that change has occurred nevertheless. The notion that cross- and transborder phenomena and perspectives are both valid and necessary is widely accepted (Mahlert and Kron, forthcoming in 2020). For example, the biannual conferences of the German Sociological Association were focused on "transnational social forms" in 2010 and on "complex dynamics of global and local developments" in 2018; these invited several thousand German-speaking sociologists to make at least some sort of connection between their work and a transnational or global perspective. ${ }^{1}$ Formerly marginal research fields such as migration studies have moved towards the core of the discipline, with textbooks (Faist et al., 2013 [Engl.]; 2014 [Germ.]; Nowicka, 2019) and original theoretical works contributing to and combining with recent theoretical developments such as Luhmannian systems theory, Bourdieuian field theory, and relational sociology as well as to new methods such as network analysis.

Since debates on globalization and transnationalization are international debates with the well-known hegemony of authors situated in US and British academia, German-speaking scholars are rarely at the core of these research fields. Nevertheless, certain individuals have made significant contributions in English and German, and some schools of thought relate to the larger field of German-language sociology in a way that gives English-language debates a distinct twist.

One important contribution of German-language sociology is theoretical endeavors to add precision to the terms globalization and transnationalization. Ludger Pries (2008a: 119-167) differentiates between seven types of cross-border phenomena. Four of these constellations use absolutist “container” notions of space, namely, internationalization, re-nationalization, supra-nationalization (e.g., the EU), and truly

1 It is worth noting that the buzzword globalization appears in many publications that deal with entirely different subjects. 
global phenomena, such as climate change, which affects regions all over the world. Pries uses relational concepts of space (Löw, SPACE. URBAN, RURAL, TERRITORIAL, this volume) to distinguish between three further socio-geographical constellations. Glocalization is the term that he suggests using if global phenomena achieve a distinctly local form and local forms universalize (cf. Robertson, 1992). Jazz, for example, originated in specific towns in the US, was later universalized, and then took on local qualities again in countries like Germany. The term diaspora-internationalization addresses spatial relations that extend across borders with a (virtual) center, such as Chinese emigrant networks. Consequently, Pries calls for more precision in using the term transnationalization: "transnational societal spaces can be understood as plurilocal frames of reference that structure everyday practices, social positions, biographical employment projects and human identities, and that span locales above, between and beyond the contexts of national container societies" (Pries, 2005: 180). Transnationalization thus connects locales in different states, whereas global studies focus on macrosocial and globally expansive phenomena. The other constellations in Pries' heuristic allow for new combinations and clarify the ways in which the nationstate frame has been modified.

Whereas migration scholars such as Pries have built on empirical findings in order to propose middle-range theories of transnational social space, the Luhmannian school of systems theory has translated a comprehensive theoretical program into research on the diffusion of global standards (section 2). Complementarily to this distinctly German-language scholarship, scholars situated in German-language academia have also contributed to the internationally hegemonic research paradigms by combining their interest in (intersectional) inequalities with studies of cultural hegemony. This research typically combines theoretical efforts with specific empirical interests, thereby contributing to a broad variety of topics ranging from migration studies and the global division of labor to the cultural aspects of globalization (section 3). In all of these schools the methods are different (section 4). Country comparisons and qualitative case studies are the most common but have been augmented by methodological innovation.

\section{Systems Theory on World Society and the Emergence of Global Standards}

When the German systems theorist Niklas Luhmann moved past Parsonian structural differentiation, he changed the foundation of his systems theory from action to communication. This move solved many theoretical problems and resulted in an elaborate and fascinating systems theory that has not been discussed much in the English-language sociological literature. ${ }^{2}$ Since communication technologies had

2 A small fraction of Luhmann's work has been translated (1995; 2000; 2012/2013), but the central 
gone global, the move towards communication also compelled Luhmann to give his theory a global scope, even though he himself did not have much interest in global studies (Luhmann, 1975; 2012/2013). ${ }^{3}$ The second and third generation of his school expanded in this direction and published extensively on world society (Heintz et al., 2005). They also established an Institute for World Society Studies in Bielefeld, Germany, thereby consolidating networks that reach as far as Latin America (Birle et al., 2012).

Compared to established globalization theories that tend to focus on politics, culture, or the political economy (Wallerstein), Luhmannian world-society theory considers multiple systems and their functionally differentiated logics. It does so with the help of an overarching and consistent systems-theoretical language. Historical processes are reinterpreted as the consecutive differentiation of functionally autonomous societal subsystems, such as religion, law, economy, politics, arts, science, intimacy, education, sports, and mass media (Stichweh, 2005: 163-177). This has enabled research on differentiated societal subsystems, which have set the stage for world society to emerge, for instance, in the form of world trade (Münch, 2011), world politics (Albert, 2016), world sports (Werron, 2010), and the globality of religion (Beyer, 2006; Petzke, 2014).

Luhmannians do not dispute that the economy is an important driver of globalization, but their theory emphasizes a constructivist approach to globalization processes. Most societal subsystems are seen as inherently universalizing owing to their dependence on symbolically generalized media such as money, power, or truth. In the last decade, Luhmannians have taken up arguments from neo-institutional worldpolity theory (Holzer et al., 2014) in studying the diffusion of social forms, standards, and self-descriptions. Thus, the term world society itself is seen as creating its own reality (Heintz et al., 2005; Kastner, 2015). Drawing on a historical study on the emergence of world sports, Werron argues that the establishment of events, criteria, and publics that enable global comparison offers an explanation for the dynamics through which some societal systems globalize (Werron, 2007; 2010). Neo-institutionalism has also informed the research designs of scholars in Bielefeld, who in turn have undertaken research on the diffusion of German social policies to China (Leisering and Liu, 2010) or on the emergence and diffusion of direct cash transfers in the Global South (Leisering, 2019; Pfau-Effinger/Grages, SOCIAL POLICY, this volume).

The constructivism that Luhmannians share with neo-institutionalists yields a highly self-reflexive theory but also creates contradictions. First, it is difficult to address global inequalities within the scope of a communication-based differentiation

debates are published in German. For introductions, see the English-language publications cited here.

3 In consequence, Luhmann and several of his acolytes turned to outdated versions of modernization theory in addressing the Global South. Modernization theory is still pre-eminent in German sociology (Haller in collaboration with Anja Eder, 2016; Preyer, 1998), which might explain some of the reluctance of English-speaking audiences to read further. 
theory. One strand of the debate attempts to replace a study of inequalities with a study of in- and exclusion (Dutra Torres, 2013; Farzin, 2006; Stichweh, 2005). A group of actor-centered differentiation theorists have also proposed the combination of theories of differentiation, inequality, and cultural hegemony (Schimank, 2015; Schwinn, 2004; Weiß, 2017; 2020) (Schimank, SOCIETY, this volume). A third argument emphasizes that, while Luhmann may have been skeptical of the continued significance of class stratification, his theory can help us understand the ambiguous position of migrants in relation to the nation state. In this reading, the reliance of the political system on territorial segmentation into nation states is seen as an exception to the rule of functional differentiation. By in- and excluding entire persons as citizens, the political system creates a threshold of inequality at national borders (Bommes, 1999; 2000; 2011).

This argument connects well with a second problem in the theory, that is, the continued relevance of the nation state in processes of globalization. Although Luhmann emphasized the primacy of functional differentiation, recent publicationsboth from the Luhmannian school and beyond-argue that national closure and globalization go hand in hand (Nowicka, 2019; Rieger and Leibfried, 2001; Werron, 2018). Thelen (2011: 24) maintains that the rapid expansion of communication technology in the 19th century enhanced national closure as a means to reduce the sudden globalization of competition. Only later did national entities start to compete with each other, thus enabling globalization processes and leading to the emergence and diffusion of international standards. Mahlert (2018) has gone on to show that global standards can actually allow for local variation.

Finally, much like Wallerstein, Luhmann argues for a theory of world society in which the nation state should only matter as a means of secondary differentiation in the subsystem of politics, yet both have inspired empirical studies that take the nation state for granted and pursue country-comparative research (Bornschier, 2002; Suter, 2010). We will come back to this point in the fourth section on methodology.

\section{Economic Inequalities and Cultural Hegemony}

A complementary body of theories is actor-centered and focuses on global and intersectional inequalities. In this area, German-speaking scholars have contributed to international debates, including those in the postcolonial and poststructuralist tradition. Key proponents in German academia represent a younger generation of scholars and include some immigrants from Eastern Europe. In studying European migration, Amelina (2017), for instance, argues for a "strong" version of the North American boundary approach, in which cultural distinctions take precedence over socially unequal relations. Cultural distinctions are also addressed through the lens of intersectional theory (Barglowski, 2019). These scholars share Luhmann's radical constructivism, but they approach research on globalization and transnationalism from a different, critical angle. Rooted in the Bourdieuian Marxist tradition, Rehbein 
and Souza (2014) have recently offered a critical reading in which they posit that the prevalent liberal-capitalist ideologies veil the fact that historical sociocultures continue to structure inequalities all over the world.

Other scholars have focused on the ways in which economic and cultural processes co-constitute global inequalities (Lenger and Schumacher, 2015). Boatcă (2015) stands out by explicitly connecting Wallersteinian Marxism with a postcolonial critique. She has revived another Bielefeld school-a 1970s feminist group that recalled Rosa Luxemburg's argument that capitalism profits most from the exploitation of subsistence labor (Mies et al., 1988). In this reading, both the exploitation of coerced and underpaid reproductive labor in the Global South and the exploitation of women by men-in both the North and the South-serve to justify economic exploitation through cultural hegemony. Today these global relations of inequality are institutionalized in citizenship regimes, extraterritorial EU migration control (Hess and Karakayali, 2007), and a comprehensive governance of all kinds of cross-border mobility (Laube, 2013; Mau et al., 2012). Similar combinations of capitalism, hegemony, national regulation, and the global division of labor are discussed as part of regulation theory (Hartmann et al., 2009).

All of these theories are interested in global and transnational inequalities between social positions, and these positions are seen as both economically structured and culturally contested. This explains the attractiveness of Bourdieuian concepts. Some German-speaking authors have discussed the concept of habitus as being transnational (Dahinden, 2011; Girard and Bauder, 2007; Weiß, 2014). In this vein, although without explicit reference to Bourdieu, Mau (2007 [Germ.]; 2010 [Engl.]) showed that the degree of transnational social connections correlates with higher income and education for the German non-migrant population. In this same line of reasoning, but explicitly drawing on Bourdieu, Gerhards et al. (2016) looked at middleand upper-class parents' attempts to transnationalize the cultural capital of their children in an effort to give them access to transnational careers. The international hypothesis of a transnational capitalist class (Carroll, 2010) has been contested in Germany: Hartmann (2016) and Schneickert (2015; 2018) have found evidence that economic elites mostly live and act in their country of origin, even in the Global South. Other research has shown that transnational lifestyles and positions are more prevalent in the professions (Büttner and Mau, 2014) and amongst mid-level expatriate managers (Kreutzer and Roth, 2006; Mense-Petermann and Klemm, 2009).

Labor and industrial relations researchers have gone beyond a mere analysis of class positions as such by studying the national and transnational regulatory frames that govern these positions. German-language research offers insight into the peculiar position of an export economy strong in industrial production. Studies on the auto industry have focused on changing divisions of labor between connected production locations (Herrigel et al., 2017). Haipeter et al. (2019) studied multilevel and transnational industrial relations. Concerning IT-labor markets, Kämpf (2008) found that outsourcing had a negative impact on IT professionals situated in Germany. MayerAhuja (2011) rejected simple dichotomies in which (high-skilled) employees in Ger- 
many lose social protection as a result of outsourcing while employers exploit differences between regulatory regimes. She studied labor-utilization strategies in two software companies in Germany and India and discovered that these strategies responded not only to global divisions of labor but also to more local and transnational regulations. Her conclusion is that the global is not homogenous and the local does not maximize difference. Pries (2010) studied the emergence of global and transnational labor regulations. Others have looked at transnational standards in (labor) markets as well as transnational professional communities (Quack et al., 2018).

This "institutional turn" in studies of transnationalization calls for further conceptualization (Quack, 2009). With a research focus on citizenship, Faist (2000c) distinguished between migrant networks, circuits of exchange, and transnational communities. He prefers the term "trans-state" to "transnational" (Faist, 2000a; 2000b) since transnational communities are often held together by a shared ethnicity and national imagination as they cross "state" borders, thus becoming "trans-state" rather than "trans-national." However, this convincing argument did not prevail.

Another conceptual debate concerns transnational chains of care. In this debate the emphasis on (migrant) labor has been expanded by considering reproductive labor, gender, and ethnic relations from an intersectional perspective (Hess, 2005; Karakayali, 2010; Lutz, 2006; Rerrich, 2006; Shinozaki, 2015). Connecting with feminist regulation theory (Aulenbacher et al., 2014), this literature finds that the incorporation of Northern women into gainful employment has changed the reproductive regime: as middle-class women could not convince their spouses to contribute to reproductive work, the ensuing gap is being closed by migrant women. Their often illegal employment then results in a shortage of care in their families of origin.

One of the English-language classics in this school of thought is Parreñas' study of Filipina domestic workers in the United States. Parreñas concept of "contradictory class mobility” (Parreñas, 2001: 150) was replicated by Nieswand's (2011) study of the status paradox that Ghanaian immigrants experience in Germany and Ghana. In both studies, class or status positions become ambiguous in relation to more than one nation state. Migrants with some degree of education are reduced to "unskilled" jobs in the service economy of the country of arrival. At the same time, global economic disparities enable them to establish a middle-class position for themselves and their families in the country of origin. Nieswand also found a negative impact on social order in Ghana when highly educated Ghanaians who stayed in the country are bested by less-educated emigrants working 3D (dirty, dangerous, and demanding) jobs abroad.

The combined analysis of country of arrival and country of origin is one of the most important achievements in empirical migration research (Pries, MIGRATION, this volume). Nowicka (2014) studied the labor-market integration and social self-positioning of Polish migrants in Great Britain. The Polish educational system produces a large number of university-educated young people whose education and income expectations do not match the demands and means offered in local labor markets. Many emigrated after EU accession. Working dead-end jobs in the United Kingdom, they 
attempt to mitigate their relegation to these menial positions by touting the superiority of their Polish education. Scheel and Gutekunst (2019) studied how potential marriage migrants relate to family and migration regimes in North Africa and the EU. In order to marry in an Islamic state, for example, the bride must show that she is a virgin. Regulations in countries of origin thus train couples in strategic self-representation, which is also needed when interacting with an EU embassy awarding the coveted family reunification visa. Especially when Northern middle-aged women marry young African men, these couples submit intimate social media content as evidence to convince embassy officers that their love is genuine. Much like Nowicka, Scheel and Gutekunst argue that institutions in the countries of origin socialize potential migrants in a manner that impacts their migration trajectories and positionings in the country of arrival.

All of these studies examine cultural struggle through the lens of global inequality studies. This is most apparent in Wimmer's concept of "culture as compromise." By referencing implicit knowledge (Mannheim) or habitus (Bourdieu), Wimmer theorizes about culture in connection with migration scholarship. Rather than essentializing the implicit knowledge aspect of culture, Wimmer (2005: 32-33) instead follows a process perspective in which continuous symbolic negotiations result in unstable cultural compromise. Once achieved, cultural compromise also closes social groups to outsiders.

However, from the perspective of cultural sociologists, culture should not be reduced to critical readings of inequality and closure. Duscha et al. have argued that "every global process is also engaged in local action in every of its aspects. [...] global concepts are all but contested [...], they are in fact strengthened by the local claims of concretization" (2018: 3). Their view hearkens back to Beck's cosmopolitization claim that "the 'global other' is in our midst" (2014:169) and is corroborated by studies of identities (Dürrschmidt, 2013), the global justice versus global competition narratives (Schreiber, 2015), transnational media (Hepp et al., 2011), and global civil society movements (Beyeler, 2013; Brand et al., 2016; Herkenrath, 2011; Unrau, 2018).

\section{Research Design and Methodologies}

As mentioned above, globalization studies often opt for country comparisons, whereas transnational studies tend to be case oriented. A few quantitative and mixed-methods studies have explored innovative sampling and research designs. Wiesböck and Verwiebe (2017) replicated Massey's ethnosurvey (1987) for the larger Vienna-Bratislava region in which Hungarians, Slovaks, and Czechs commute to Austria. Guveli et al. (2017) sampled guest-worker emigrants and a contrast group of non-migrants in five Turkish provinces as well as the second and third generation in their families who now often reside in Western Europe. Dahinden (2009) identified four ideal types of (non-) migrants in a small Swiss town and described their characteristics with a quantitative descriptive network analysis. One of the four types are the locally established Swiss. 
Even for them, Dahinden found that $13 \%$ of their social ties are transnational. Greschke (2009) is notable for the ethnographic study of a case in virtual space. She showed for a Latin American social-media website how virtual events and spaces intertwine with nationally framed and geographically situated practices.

Research designs of this kind contribute to a debate about the proper units of analysis in global and transnational research (Pries, 2008b). Internationally, the field concept is used for nationally framed topics (Fligstein and McAdam, 2012), in studies of transnationalization (Levitt and Glick Schiller, 2004), and for studying globalization (Go and Krause, 2016). German-language publications referenced Bourdieu earlier than generally was the case in the international debate in order to theorize societal entities that go beyond the nation state. Participants in a Bourdieuian field do not share generalized media of communication (which define Luhmann's systems) but rather an illusio that must be incorporated much like a habitus. As mentioned above, transnational habitus is a contested concept, which explains why Bongaerts (2008) expects habitus to globalize only in part and in very specific fields. Empirical research in this tradition does indeed prioritize specific fields, mostly politics and the economy, and those pursuing it often argue that members of an emerging transnational faction compete with their nationally oriented counterparts (Bernhard and Schmidt-Wellenburg, 2012; Bühlmann et al., 2013; Witte and Schmitz, 2017). A study by Buchholz (2008) showed that art is globalizing as North-South hierarchies continue to persist. This is because very few artists from peripheral countries were found to gain access to the art world even after staying in the North for extended periods of time and accumulating social capital there. To the extent that they are successful, their success comes at the price of selling their art as "ethnic."

Another methodological option is a radical turn toward the local and the ways in which global phenomena are enacted in micro-social interaction (Berking, 2006; Knorr-Cetina, 2012). In an ethnographic study on consumption practices among Chinese students, Meinhof (2018) refuted notions of modern individuality and globalizing individualization. Instead he identified two divergent micro dispositives, the shopping mall and the market stall. Both suggest a specific type of shopping practice in which the global and local combine. Building on prevalent critiques of Eurocentric theorizing, Rehbein (2013) avoided the Scylla of definitive laws and the Charybdis of hyping hybridity by offering a kaleidoscopic dialectic built on Adorno's relational constellations and Wittgenstein's family resemblances, namely, the fact that every historical trajectory is different does not preclude a contextualized analysis of "resemblances.”

\section{Towards Global and Transnational Studies}

In the 1980s, research on "globalization" and "transnationalization" seemed to open new avenues for theory and empirical research. The enthusiasm of that time is long gone. It did, however, stimulate a wealth of innovation. Among German-speaking 
authors after the turn of the millennium, we can discern a collective effort towards better and more precise theories of globalization and transnationalism. First, Beck and Luhmann were compelled to give their comprehensive theories a distinctly global twist. Later, more empirically minded migration scholars suggested middle-range heuristics or expanded on Bourdieuian field and capital terminologies. More recently, theorists have combined cultural hegemony and economic analyses. Transnational studies of labor and migration not only contribute to a better understanding of the continued relevance of nationalism and the nation state but also consider more than one national context at the same time.

As a general trend, empirical studies often focus on highly specific phenomena such as transnational (migratory) networks, the outsourcing of labor, or elite reproduction, whereas theoretical work tends to debate the theory of society (Römer, 2014). Frequent calls for “decentering” migration (Dahinden, 2016; Nieswand, 2016) or for transnationalizing sociology have not yet been answered by a comprehensive and convincing sociological approach to global and transnational studies. Rather, grand theories tend to focus on systems and forget agency or to give cultural hegemony and the positioning strategies of individual and collective agents primacy over an analysis of institutions. Combined theories do exist, though, and empirical research does offer elaborate, albeit case-study-based analyses of the ways in which globality is expressed and shaped by micro and meso situations. The next few decades might see the emergence of a paradigm that can theorize society beyond the nation state and that can guide comprehensive transnational research.

\section{References}

Albert, M. A Theory of World Politics; Cambridge University Press: Cambridge, UK, 2016.

Amelina, A. Transnationalizing Inequalities in Europe: Sociocultural Boundaries, Assemblages and Regimes of Intersection; Routledge: New York, 2017.

Aulenbacher, B.; Riegraf, B.; Theobald, H., Eds. Sorge. Arbeit, Verhältnisse, Regime. Soziale Welt, Sonderband 20; Nomos: Baden-Baden, 2014.

Barglowski, K. Cultures of Transnationality in European Migration. Subjectivity, Family and Inequality; Routledge: London, 2019.

Beck, U. World Risk Society; Polity Press: Malden, MA, 1999.

Beck, U., Ed. Ulrich Beck. Pioneer in Cosmopolitan Sociology and Risk Society; Springer: Cham, 2014.

Beck, U.; Poferl, A. Eds. Große Armut, großer Reichtum. Zur Transnationalisierung sozialer Ungleichheit; Suhrkamp: Berlin, 2010.

Beck, U.; Sznaider, N.; Winter, R., Eds. Globales Amerika? Die kulturellen Folgen der Globalisierung; transcript: Bielefeld, 2003.

Beck, U.; Blok, A.; Tyfield, D.; Zhang, J. Y. Cosmopolitan Communities of Climate Risk: Conceptual and Empirical Suggestions for a new Research Agenda. Global Networks 2013, 13, 1-21.

Berking, H. Die Macht des Lokalen in einer Welt ohne Grenzen; Campus: Frankfurt a.M./New York, 2006.

Bernhard, S.; Schmidt-Wellenburg, C., Eds. Feldanalyse als Forschungsprogramm (2 Vol.); VS: Wiesbaden, 2012. 
Beyeler, M. Was bewirkt Globalisierungskritik. Protestkampagnen gegen die Welthandelsorganisation und das Weltwirtschaftsforum.; Campus: Frankfurt a.M., 2013.

Beyer, P. Religions in Global Society; Taylor \& Francis: London/New York, 2006.

Birle, P.; Dewey, M.; Mascareño, A. Durch Luhmanns Brille. Herausforderungen an Politik und Recht in Lateinamerika und in der Weltgesellschaft.; Springer VS: Wiesbaden, 2012.

Boatcă, M. Global Inequalities Beyond Occidentalism; Ashgate: Aldershot, 2015.

Bommes, M. Migration und nationaler Wohlfahrtsstaat. Ein differenzierungstheoretischer Entwurf; Westdeutscher Verlag: Opladen, 1999.

Bommes, M. National Welfare State, Biography and Migration. Labour Migrants, Ethnic Germans and the Re-Ascription of Welfare State Membership. In Immigration and Welfare. Challenging the Borders of the Welfare State; Bommes, M.; Geddes, A., Eds.; Routledge: London, 2000; pp 90-108.

Bommes, M. Migration in der modernen Gesellschaft. IMIS-Beiträge 2011, 38, 53-72.

Bongaerts, G. Verdrängungen des Ökonomischen. Bourdieus Theorie der Moderne; transcript: Bielefeld, 2008.

Bornschier, V. Weltgesellschaft. Grundlegende soziale Wandlungen; Loreto: Zurich, 2002.

Brand, U.; Schwenken, H.; Wullweber, J., Eds. Globalisierung analysieren, kritisieren und verändern. Das Projekt Kritische Wissenschaft; VSA: Hamburg, 2016.

Buchholz, L. Feldtheorie und Globalisierung. In Nach Bourdieu: Visualität, Kunst, Politik; von Bismarck, B.; Kaufmann, T.; Wuggenig, U., Eds.; Turia + Kant: Vienna, 2008; pp 211-238.

Bühlmann, F.; David, T.; Mach, A. Cosmopolitan Capital and the Internationalization of the Field of Business Elites: Evidence from the Swiss Case. Cultural Sociology 2013, 7, 211-229.

Büttner, S.; Mau, S. EU-Professionalismus als transnationales Feld. Berliner Journal für Soziologie 2014, 24, 141-167.

Carroll, W. K. The Making of a Transnational Capitalist Class. Corporate Power in the 21st Century; ZED: London, 2010.

Dahinden, J. Are we all Transnationals now? Network Transnationalism and Transnational Subjectivity: The Differing Impacts of Globalization on the Inhabitants of a Small Swiss City. Ethnic and Racial Studies 2009, 32, 1365-1386.

Dahinden, J. Wer entwickelt einen transnationalen Habitus? Ungleiche Transnationalisierungsprozesse als Ausdruck ungleicher Ressourcenausstattung. In Die soziale Welt quer denken. Transnationalisierung und ihre Folgen für die Soziale Arbeit; Reutlinger, C.; Baghdadi, N.; Kniffki, J., Eds.; Frank \& Timme: Berlin, 2011; pp 83-107.

Dahinden, J. A Plea for the 'De-Migranticization' of Research on Migration and Integration. Ethnic and Racial Studies 2016, 39, 2207-2225.

Dürrschmidt, J. Rückkehr aus der Globalisierung? Der Heimkehrer als Sozialfigur der Moderne; Hamburger Edition: Hamburg, 2013.

Duscha, A.; Klein-Zimmer, K.; Klemm, M.; Spiegel, A. Understanding Transnational Knowledge. Transnational Social Review 2018, 8, 2-6.

Dutra Torres, R. Funktionale Differenzierung, soziale Ungleichheit und Exklusion; UVK: Constance/Munich, 2013.

Faist, T. Jenseits von Nation und Post-Nation. Transstaatliche Räume und Doppelte Staatsbürgerschaft. Zeitschrift für Internationale Beziehungen 2000a, 7, 109-144.

Faist, T. Soziale Bürgerschaft in der Europäischen Union: Verschachtelte Mitgliedschaft. In Die Europäisierung nationaler Gesellschaften. Soziale Welt, Sonderheft 40; Bach, M., Ed.; Westdeutscher Verlag: Opladen, 2000b; pp 229-250.

Faist, T. The Volume and Dynamics of International Migration and Transnational Social Spaces; Clarendon Press: Oxford, 2000c. 
Faist, T.; Fauser, M.; Reisenauer, E. Das Transnationale in der Migration: Eine Einführung; Beltz Juventa: Weinheim/Basel, 2014 [Transnational Migration; Polity Press: Cambridge, Malden, 2013].

Farzin, S. Inklusion/Exklusion. Entwicklungen und Probleme einer systemtheoretischen Unterscheidung; transcript: Bielefeld, 2006.

Fligstein, N.; McAdam, D. A Theory of Fields; Oxford University Press: New York, 2012.

Gerhards, J.; Hans, S.; Carlson, S. Klassenlage und transnationales Humankapital. Wie Eltern der mittleren und oberen Klassen ihre Kinder auf die Globalisierung vorbereiten; Springer VS: Wiesbaden, 2016 [Social Class and Transnational Human Capital. How Middle and Upper Class Parents Prepare Their Children for Globalization; Routledge: Abingdon/New York, 2017].

Girard, E. R.; Bauder, H. Assimilation and Exclusion of Foreign Trained Engineers in Canada: Inside a Professional Regulatory Organization. Antipode 2007, 39, 35-53.

Go, J.; Krause, M. Fielding Transnationalism: An Introduction. The Sociological Review 2016, 64, 6-30.

Greschke, H. Daheim in www.cibervalle.com. Zusammenleben im medialen Alltag der Migration; Lucius \& Lucius: Stuttgart, 2009.

Guveli, A.; Ganzeboom, H. B. G.; Baykara-Krumme, H.; Platt, L.; Eroğlu, Ş.; Spierings, N.; Bayrakdar, S.; Nauck, B.; Sozeri, E. K. 2,000 Families: Identifying the Research Potential of an Origins-of-Migration Study. Ethnic and Racial Studies 2017, 40, 2558-2576.

Haipeter, T.; Hertwig, M.; Rosenbohm, S. Vernetzt und verbunden - Koordinationsprobleme im Mehrebenensystem der Arbeitnehmervertretung; Springer VS: Wiesbaden, 2019.

Haller, M.; in Collaboration with Eder, A. Ethnic Stratification and Economic Inequality around the World. The End of Exploitation and Exclusion?; Routledge: Abingdon/New York, 2016.

Hartmann, E.; Kunze, C.; Brand, U., Eds. Globalisierung, Macht und Hegemonie; Westfälisches Dampfboot: Münster, 2009.

Hartmann, M. Die globale Wirtschaftselite. Eine Legende; Campus: Frankfurt a.M./New York, 2016.

Heintz, B.; Münch, R.; Tyrell, H. Weltgesellschaft. Theoretische Zugänge und empirische Problemlagen, Sonderheft der Zeitschrift für Soziologie; Lucius \& Lucius: Stuttgart, 2005.

Hepp, A.; Bozdag, C.; Suna, L. Mediale Migranten. Mediatisierung und die kommunikative Vernetzung der Diaspora; VS: Wiesbaden, 2011.

Herkenrath, M. Die Globalisierung der sozialen Bewegungen. Transnationale Zivilgesellschaft und die Suche nach der gerechten Weltordnung; VS: Wiesbaden, 2011.

Herrigel, G.; Voskamp, U.; Wittke, V. Globale Qualitätsproduktion. Transnationale Produktionssysteme in der Automobilzulieferindustrie und im Maschinenbau; Campus: Frankfurt a.M./New York, 2017.

Hess, S. Globalisierte Hausarbeit. Au-pair als Migrationsstrategie von Frauen aus Osteuropa; VS: Wiesbaden, 2005.

Hess, S.; Karakayali, S. New Governance oder die imperiale Kunst des Regierens. Asyldiskurs und Menschenrechtsdispositiv im neuen EU-Migrationsmanagement. In Turbulente Ränder. Neue Perspektiven auf Migration an den Grenzen Europas; Transit Migration Forschungsgruppe, Eds.; transcript: Bielefeld, 2007; pp 39-55.

Holzer, B.; Kastner, F.; Werron, T. Eds. From Globalization to World Society. Neo-Institutional and Systems-Theoretical Perspectives; Routledge: London, 2014.

Kämpf, T. Die neue Unsicherheit. Folgen der Globalisierung für hochqualifizierte Arbeitnehmer; Campus: Frankfurt a.M./New York, 2008.

Karakayali, J. Transnational Haushalten. Biographische Interviews mit "care workers" aus Osteuropa.; VS: Wiesbaden, 2010.

Kastner, F. Transitional Justice in der Weltgesellschaft; Hamburger Edition: Hamburg, 2015. 
Knorr-Cetina, K. What is a Financial Market? Global Markets as Microinstitutional and Post-Traditional Social Forms. In The Oxford Handbook of the Sociology of Finance; Knorr-Cetina, K.; Preda, A., Eds.; Oxford University Press: Oxford, 2012; pp 115-133.

Kreutzer, F.; Roth, S., Eds. Transnationale Karrieren. Biografien, Lebensführung und Mobilität; VS: Wiesbaden, 2006.

Krossa, A. S. Gesellschaft. Betrachtungen eines Kernbegriffs der Soziologie; Springer VS: Wiesbaden, 2018.

Laube, L. Grenzkontrollen jenseits nationaler Territorien. Die Steuerung globaler Mobilität durch liberale Staaten; Campus: Frankfurt a.M./New York, 2013.

Leisering, L. The Global Rise of Social Cash Transfers. How States and International Organizations Constructed a New Instrument for Combating Poverty; Oxford UP: Oxford, 2019.

Leisering, L.; Liu, T. Globale Wissensdiffusion in der Sozialpolitik. Die Einführung einer Arbeitsunfallversicherung in der Volksrepublik China. Zeitschrift für Sozialreform 2010, 56, 173-205.

Lenger, A.; Schumacher, F. The Global Configurations of Inequality: Stratification, Glocal Inequalities, and the Global Social Structure. In Understanding the Dynamics of Global Inequality. Social Exclusion, Power Shift, and Structural Changes; Lenger, A.; Schumacher, F., Eds.; Springer: Heidelberg/New York/Dordrecht/London, 2015; pp 3-46.

Lessenich, S. Neben uns die Sintflut; Hanser: Berlin, 2016.

Levitt, P.; Glick Schiller, N. Conceptualizing Simultaneity: A Transnational Social Field Perspective on Society. International Migration Review 2004, 38, 1002-1039.

Luhmann, N. Die Weltgesellschaft. In Soziologische Aufklärung. Band 2: Aufsätze zur Theorie der Gesellschaft; Luhmann, N.; Westdeutscher Verlag: Opladen, 1975; pp 51-71.

Luhmann, N. Social Systems; Stanford University Press: Stanford CA, 1995.

Luhmann, N. Art as a Social System; Stanford University Press: Stanford, CA, 2000.

Luhmann, N. Theory of Society (2 vol.). Translated by Rhodes Barrett; Stanford University Press: Stanford, CA, 2012/2013.

Lutz, H. Vom Weltmarkt in den Privathaushalt. Die neuen Dienstmädchen im Zeitalter der Globalisierung; Barbara Budrich: Leverkusen/Opladen, 2006.

Mahlert, B. Dividing What is Particular from what is Universal: The Human Development Index in a Systems Theoretical Perspective. Transnational Social Review 2018, 8, 7-19.

Mahlert, B; Kron, T. Kosmopolitische Ungleichheitssoziologie. In Soziologische Phantasie und kosmopolitisches Gemeinwesen. Perspektiven einer Weiterführung der Soziologie Ulrich Becks. Sonderband der Sozialen Welt; Holzinger, M.; Römer, O.; Boehncke, C., Eds.; Nomos: Baden-Baden, forthcoming 2020.

Massey, D. S. The Ethnosurvey in Theory and Practice. The International Migration Review 1987, 21, 1498-1522.

Mau, S. Transnationale Vergesellschaftung. Die Entgrenzung sozialer Lebenswelten; Campus: Frankfurt a.M./New York, 2007 [Social Transnationalism. Lifeworlds Beyond The Nation-State; Routledge: London/New York, 2010].

Mau, S.; Brabandt, H.; Laube, L.; Roos, C. Liberal States and the Freedom of Movement: Selective Borders, Unequal Mobility; Palgrave Macmillan: Basingstoke/New York, 2012.

Mayer-Ahuja, N. Grenzen der Homogenisierung. IT-Arbeit zwischen ortsgebundener Regulierung und transnationaler Unternehmensstrategie; Campus: Frankfurt a.M./New York, 2011.

Meinhof, M. Shopping in China; Springer VS: Wiesbaden, 2018.

Mense-Petermann, U.; Klemm, M. Der “Globalmanager” als neuer Managertypus? Eine Fallstudie zu Transnationalisierungsprozessen im Management. Zeitschrift für Soziologie 2009, 38, 477-493.

Mies, M.; Bennholdt-Thomsen, V.; Werlhof, C.v., Eds. Women, the Last Colony; Zed Books: London, 1988. 
Münch, R. Das Regime des Freihandels. Entwicklung und Ungleichheit in der Weltgesellschaft; Campus: Frankfurt a.M./New York, 2011 [The Global Division of Labour. Development and Inequality in World Society; Palgrave Macmillan: Basingstoke/New York, 2016].

Nieswand, B. Theorising Transnational Migration. The Status Paradox of Migration; Routledge: New York/London, 2011.

Nieswand, B. Die Dezentrierung der Migrationsforschung. In Migration - Religion - Identität. Aspekte transkultureller Prozesse; Kazzazi, K.; Treiber, A.; Wätzold, T., Eds.; Springer VS: Wiesbaden, 2016; pp 283-297.

Nowicka, M. Migrating Skills, Skilled Migrants and Migration Skills: The Influence of Contexts on the Validation of Migrants' Skills. Migration Letters 2014, 11, 171-186.

Nowicka, M. Transnationalismus. Umriss eines Paradigmas; Nomos: Baden-Baden, 2019.

Parreñas, R. S. Servants of Globalization: Women, Migration, and Domestic Work; Stanford University Press: Stanford, CA, 2001.

Petzke, M. Weltbekehrungen. Zur Konstruktion globaler Religion im pfingstlich-evangelikalen Christentum; transcript: Bielefeld, 2014.

Preyer, G., Ed. Strukturelle Evolution und das Weltsystem. Theorien, Sozialstruktur und evolutionäre Entwicklungen; Suhrkamp: Frankfurt a.M., 1998.

Pries, L. Configurations of Geographic and Societal Spaces: A Sociological Proposal between 'Methodological Nationalism' and the 'Spaces of Flows'. Global Networks 2005, 5, 167-190.

Pries, L. Die Transnationalisierung der sozialen Welt. Sozialräume jenseits von Nationalgesellschaften; Suhrkamp: Frankfurt a.M., 2008a.

Pries, L. Transnational Societal Spaces. Which Units of Analysis, Reference and Measurement? In Rethinking Transnationalism. The Meso-Link of Organisations; Pries, L., Ed.; Routledge: London, 2008b; pp 1-20.

Pries, L. Erwerbsregulierung in einer globalisierten Welt; VS: Wiesbaden, 2010.

Quack, S. 'Global' Markets in Theory and History: Towards a Comparative Analysis. In Wirtschaftssoziologie; Beckert, J.; Deutschmann, C., Eds.; VS: Wiesbaden, 2009; pp 125-142.

Quack, S.; Schulz-Schaeffer, I.; Shire, K.; Weiß, A., Eds. Transnationalisierung der Arbeit; Springer VS: Wiesbaden, 2018.

Quijano, A. Coloniality of Power, Eurocentrism, and Latin America. Nepantla: Views from South 2000, 1, 533-580.

Rehbein, B. Kaleidoskopische Dialektik; UVK: Constance, 2013.

Rehbein, B.; Souza, J. Ungleichheit in kapitalistischen Gesellschaften; Beltz Juventa: Weinheim/Basel, 2014 [Jodhka, S.; Rehbein, B.; Souza, J. Inequality in Capitalist Socieities; Routledge: Abingdon/New York, 2018].

Rerrich, M. Die ganze Welt zu Hause. Cosmobile Putzfrauen in privaten Haushalten; Hamburger Edition: Hamburg, 2006.

Rieger, E.; Leibfried, S. Grundlagen der Globalisierung. Perspektiven des Wohlfahrtsstaats; Suhrkamp: Frankfurt a.M., 2001.

Robertson, R. Globalization. Social Theory and Global Culture; Sage: London/Newbury Park/New Delhi, 1992.

Römer, O. Globale Vergesellschaftung. Perspektiven einer postnationalen Soziologie; Campus: Frankfurt a.M./New York, 2014.

Scheel, S.; Gutekunst, M. Studying Marriage Migration to Europe from Below: Informal Practices of Government, Border Struggles and Multiple Entanglements. Gender, Place \& Culture 2019, 26, 847-867.

Schimank, U. Grundriss einer integrativen Theorie der modernen Gesellschaft. Zeitschrift für theoretische Soziologie 2015, 4, 236-268.

Schneickert, C. Nationale Machtfelder und Globalisierte Eliten; UVK: Constance, 2015. 
Schneickert, C. Globalizing Political and Economic Elites in National Fields of Power. Historical Social Research 2018, 43, 329-358.

Schreiber, D. Narrative der Globalisierung. Gerechtigkeit und Konkurrenz in faktualen und fiktionalen Erzählungen; Springer VS: Wiesbaden, 2015.

Schwinn, T. Eds. Differenzierung und soziale Ungleichheit. Die zwei Soziologien und ihre Verknüpfung; Humanities Online: Frankfurt a.M., 2004.

Shinozaki, K. Migrant Citizenship from Below. Family, Domestic Work, and Social Activism in Irregular Migration; Palgrave Macmillan: New York, 2015.

Stichweh, R. Inklusion und Exklusion; transcript: Bielefeld, 2005.

Suter, C. Ed. Inequality Beyond Globalization. Economic Changes, Social Transformations, and the Dynamics of Inequality; LIT: Münster, 2010.

Thelen, P. Vergleich in der Weltgesellschaft. Zur Funktion nationaler Grenzen für die Globalisierung von Wissenschaft und Politik; transcript: Bielefeld, 2011.

Tilly, C. Big Structures, Large Processes, Huge Comparisons; Russell Sage Foundation: New York, 1984.

Unrau, C. Erfahrung und Engagement: Motive, Formen und Ziele der Globalisierungskritik; transcript: Bielefeld, 2018.

Weiß, A. Wie erkennen sich Gleiche in der Welt? Milieutheorie unter den Bedingungen von Globalisierung. In Die Form des Milieus. Zum Verhältnis von gesellschaftlicher Differenzierung und Formen der Vergemeinschaftung. 1. Sonderband der Zeitschrift für Theoretische Soziologie; Isenböck, P.; Nell, L.; Renn, J., Eds.; Beltz Juventa: Weinheim/Basel, 2014; pp 339-356.

Weiß, A. Soziologie globaler Ungleichheiten; Suhrkamp: Berlin, 2017.

Weiß, A., Re-thinking Society. How can Sociological Theories Help Us Understand Global and Cross-border Social Contexts? Current Sociology 2020 Doi: 10.1177/0011392120936314

Werron, T. Publika. Zur Globalisierungsdynamik von Funktionssystemen. Soziale Systeme 2007, 13, 381-394.

Werron, T. Der Weltsport und sein Publikum. Zur Autonomie und Entstehung des modernen Sports; Velbrück: Weilerswist, 2010.

Werron, T. Der globale Nationalismus; Nicolai: Münster, 2018.

Wiesböck, L.; Verwiebe, R. Crossing the Border for a Higher Status? Occupational Mobility of East-West Commuters in the Central European Region. International Journal of Sociology 2017, 47, 162-181.

Wimmer, A. Kultur als Prozess; VS: Wiesbaden, 2005.

Witte, D.; Schmitz, A. Der Nationalstaat und das globale Feld der Macht, oder: Wie sich die Feldtheorie von ihrem methodologischen Nationalismus befreien lässt. Zeitschrift für theoretische Soziologie 2017, 6, 156-188. 
